
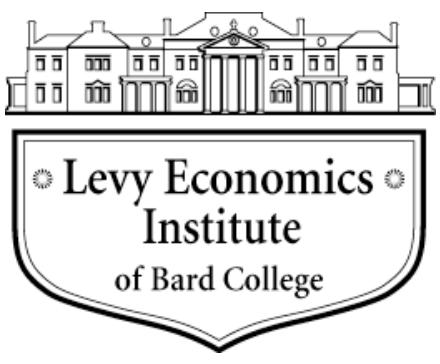

Working Paper No. 825

\title{
Why Does Brazil's Banking Sector Need Public Banks? What Should BNDES Do?
}

by

\author{
Felipe Rezende* \\ Hobart and William Smith Colleges
}

January 2015

\begin{abstract}
* Assistant professor of economics, Hobart and William Smith Colleges, and research fellow, Institute for Multidisciplinary Development and Strategy (MINDS); rezende@hws.edu

This paper was prepared for the project "Financing Innovation: An Application of a Keynes-SchumpeterMinsky Synthesis," funded in part by the Institute for New Economic Thinking, INET grant no. IN012-00036, administered through the Levy Economics Institute of Bard College. Co-principal investigators: Mariana Mazzucato (Science Policy Research Unit, University of Sussex) and L. Randall Wray (Levy Institute). The author thanks INET and the Levy Institute for support of this research.
\end{abstract}

The Levy Economics Institute Working Paper Collection presents research in progress by Levy Institute scholars and conference participants. The purpose of the series is to disseminate ideas to and elicit comments from academics and professionals.

Levy Economics Institute of Bard College, founded in 1986, is a nonprofit, nonpartisan, independently funded research organization devoted to public service. Through scholarship and economic research it generates viable, effective public policy responses to important economic problems that profoundly affect the quality of life in the United States and abroad.

Levy Economics Institute

P.O. Box 5000

Annandale-on-Hudson, NY 12504-5000

http://www.levyinstitute.org

Copyright (C) Levy Economics Institute 2015 All rights reserved

ISSN 1547-366X 
Preferred URL: why-does-brazils-banking-sector-need-public-banks-what-shouldBNDES-do

Meta Description: This Levy Institute working paper by Felipe Rezende examines the stability and resilience of Brazil's banking system in the face of the 2007-8 global financial crisis, and the question of whether it is possible that the alternative approaches followed by some developing countries might provide an indication of more stable regulatory approaches generally.

Topics: Bond Markets; Financial Markets; Securities Markets; Stabilization 


\begin{abstract}
The 2007-8 global financial crisis has shown the failure of private finance to efficiently allocate capital to finance real capital development. The resilience and stability of Brazil's financial system has received attention, since it navigated relatively smoothly through the Great Recession and the collapse of the shadow banking system. This raises the question of whether it is possible that the alternative approaches followed by some developing countries might provide an indication of more stable regulatory approaches generally. There has been much discussion about how to support private long-term finance in order to meet Brazil's growing infrastructure and investment needs. One of the essential functions of the financial system is to provide the long-term funding needed for long-lived and expensive capital assets. However, one of the main difficulties of the current private financial system is its failure to provide long-term financing, as the short-termism in Brazil's financial market is a major obstacle to financing long-term assets. In its current form, the National Economic and Social Development Bank (BNDES) is the main source of long-term funding in the country. However, BNDES has been subject to a range of criticisms, such as crowding out private sector bank lending, and it is said to be hampering the development of the local capital market. This paper argues that, rather than following the traditional approach to justify the existence of public banks - and BNDES in particular, based on market failures - finding an effective answer to this question requires a theory of financial instability.
\end{abstract}

Keywords: Bond Market; Financial Market; Security Markets; Stabilization

JEL Classifications: E00, E4, E6, G00, G1 


\section{WHY DOES BRAZIL'S BANKING SECTOR NEED PUBLIC BANKS?}

Rather than justifying the existence of public banks, and BNDES in particular, using an argument based on market failures (Garcia 2011), an effective answer to this question requires a theory of financial instability. The 2007-2008 global financial crisis had a profound impact on the state of modern economics. It exposed the failure of mainstream economics, and led to some understanding of the inherent instability of capitalism and how to prevent depressions. Moreover, the conventional approach had disastrous economic policy consequences that contributed to the Great Recession. Entering the global crisis, mainstream economists believed "the state of macro is good" (Blanchard 2009, p.2). People who were believed to have a sophisticated understanding of economics did not understand what we were getting into during the bubble years, and they repeatedly dismissed ample warnings about growing financial fragility and instability in the economy. For instance, Arminio Fraga, ex-president of the Central Bank of Brazil from 1999-2002, and currently a hedge fund manager, proclaimed the following in 2005 during the Jackson Hole Economic Policy Symposium:

[w]e are moving towards more complete markets. Presumably this is a good thing. I do see from my vantage point at the ground level that risk is going where it belongs. It is, in fact, a good innovation because small investors don't like banks to take a lot of risk. So, traders and banks move out to hedge funds and they are there met by more sophisticated investors. Banks in the old days were paid to grow their loan books, I can't think of a worse incentive, and that is the way they were compensated... Investment managers today, however risky their business may be, tend to care about their reputations and tend to have their money on the line. That is healthy and it is being delivered by the market on its own...As an investor, I have a pretty easy time looking at funds and figuring out what they are doing. It is nearly impossible to know what the large financial institutions we have in this planet are doing these days... That is, in my view, probably an argument to say we may be better off than before...Perhaps because of all this we see less of an impact of all these financial accidents on the real economy now than we did see in the 1980s when it took years to clear markets, for banks to start lending again, and for the economies to start moving (Fraga 2005, 389-390).

The unfolding of the global economic crisis has called into question both the conventional approach and mainstream economists' reputations. In a recent article about the state of macroeconomics, the IMF's chief economist Olivier Blanchard, confessed where danger really lurks, that is, in the minds and models of an orthodox economist. He acknowledged that "[traditional models have] a worldview in which economic fluctuations occurred but were regular, and essentially self correcting. The problem is that we came to 
believe that this was indeed the way the world worked" (Blanchard 2014:28). As Wray (2011) pointed out:

The global crisis exploded reigning orthodoxy. Among those theories and claims that should no longer be taken seriously by any macroeconomist we must include: rational expectations and continuous market clearing; New Classical and Real Business Cycle approaches; neutral money; the New Monetary Consensus, the Taylor rule, and the Great Moderation; the Efficient Markets Hypothesis; Ricardian equivalents and other versions of the policy irrelevance doctrine; and claims made by advocates of deregulation and self-regulation. To be sure, we have been here before. The Great Depression also exploded the reigning orthodoxy. Keynes offered a revolution in thought. Unfortunately, that revolution was aborted, or, at least, co-opted by "synthesizers" who borrowed only the less revolutionary aspects of his theory and then integrated these into the old Neoclassical approach. The important insights of Keynes were never incorporated in mainstream macroeconomics. Eventually, Neoclassical theory was restored. It is now time to throw it out, to see what should be recovered from Keynes, and to update Keynes's theory to make it relevant for the world in which we actually live (Wray 2011, p.7).

Why is this discussion important? During the pre-crisis period, developed countries' regulatory systems had been considered as "best practice" and formed the basis for recommendations to developing countries seeking to liberalize and expand their domestic financial markets. Once more, the crisis fatally discredited notions that free-market economies are inherently stable. It discredited the belief in self-regulation and supervision, as well as arguments against regulation, based on the idea that markets would undertake due diligence resulting in optimal outcomes and that market prices act as signals that agents react to in a Pareto-optimal manner. The crisis has shown the failure of private finance to efficiently allocate capital to finance real capital development.

The Great Recession called into question the "light touch" regulatory approach practiced in the US and the UK, and produced an ad-hoc response to the financial crisis. In spite of massive expansion of central banks' balance sheets in developed economies aimed at bailing out financial institutions and their intervention in private credit markets, it had little impact in terms of increasing credit to the private non-bank sector. The crisis response has raised two fundamental questions. First, the regulatory and supervisory framework put in place in advanced nations before the 2007-2008 global financial crisis failed to capture and avoid the build up of financial fragility in the economy. While the mainstream view of finance and the proper regulatory approach have been called into question, Minsky's alternative approach provides a framework to investigate structural changes in the domestic financial architecture and help the 
appropriate designing of the existing regulatory and supervisory policies to constrain the development of financial fragility in the economy and deal with severe systemic crises (Kregel 2014). In this approach, the destabilizing effects of stability on financial structures calls for dynamic adjustments to policy frameworks and brings about the need to redesign the regulatory structure to continually meet its objectives of financial stability and to provide funding for development and financing for innovation.

Second, to the extent that the financial structure that emerged in the US financial system in the past 30 years failed to provide support for the capital development of the economy and improve living standards, an alternative design of the financial structure that meets the needs of developing nations needs to be developed. For instance, the UNCTAD report noted the following:

At present, flaws in credit allocation by deregulated private banks and difficulties in reestablishing the supply of credit for the real sector in developed economies (despite expansionary monetary policies) have led to a renewed interest in credit policies. For instance, in July 2012 the Bank of England established a temporary Funding for Lending Scheme, with the goal of incentivizing banks and building societies to boost their lending to the country's real economy... The Bank of Japan had launched a similar initiative in 2010... However, these initiatives are frequently introduced as extraordinary measures for dealing with exceptional circumstances. There are strong arguments in favour of central bank and government intervention to influence the allocation of credit in normal times, especially in developing countries. Such credit should aim at strengthening the domestic forces of growth and reducing financial instability, since long-term loans for investment and innovation and loans to micro, small and mediumsized enterprises are extremely scarce even in good times (UNCTAD 2013, p.134-135).

In this regard, the resilience and stability of Brazil's financial system has received attention as it navigated relatively smoothly through the 2007-2008 global financial crisis and the collapse of the shadow banking system.

\section{WHY DOES BRAZIL'S BANKING SECTOR NEED BNDES?}

There has been much discussion about how to support private long-term finance to meet Brazil's growing infrastructure and investment needs. One of the essential functions of the financial system is to provide long-term funding needed for long-lived and expensive capital assets. However, one of the main challenges posed by the current private financial system is its failure to provide long-term financing. The short termism in Brazil's financial market is a major 
obstacle to financing long-term assets. In its current form, the National Economic and Social Development Bank (BNDES) is the main source of long-term funding in the country. In this regard, the chapter "Mobilizing domestic financial resources for development," paragraph 18, of the Monterrey Consensus noted that "Development banks, commercial and other financial institutions, whether independently or in cooperation, can be effective instruments for facilitating access to finance, including equity financing, for such enterprises, as well as an adequate supply of medium- and long- term credit” (Monterrey Consensus). To this end, UNCTAD’s 2013 Trade and Development Report noted that

Public intervention in the provision of bank credit will be especially important in developing countries that are aiming at strengthening domestic forces of growth, since long-term loans for investment and innovation, as well as loans to micro, small and medium-sized enterprises are extremely scarce even in good times. Commercial banks in developing countries often prefer to grant short-term personal loans or to buy government securities, because they consider the risks associated with maturity transformation (i.e. providing long-term credits matched by short-term deposits) to be too high...National development banks may provide financial services that private financial institutions are unable or unwilling to provide to the extent desired (UNCTAD, Trade and Development Report, 2013, p. XVII, emphasis added).

As the 2007-2008 Global Financial Crisis unfolded, BNDES sharply increased its balance sheet, mainly due to massive National Treasury loans to the Brazilian Development Bank (figures 1 and 2). It allowed BNDES to expand its balance sheet to meet Brazil's longterm investment needs and counter financial instability. ${ }^{1}$

\footnotetext{
${ }^{1}$ For more details about Brazil's response to the crisis see Barbosa (2010).
} 
Figure 1 BNDES Total Assets

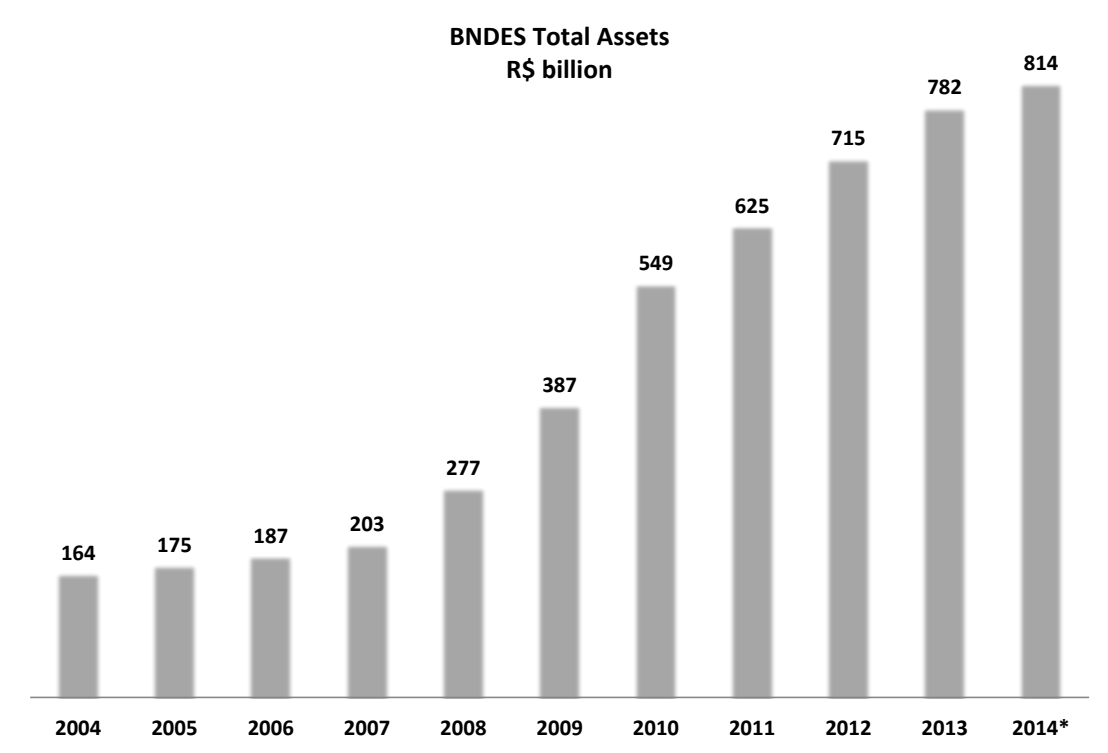

Source: BNDES

Figure 2 BNDES Funding from the National Treasury and Funds Received from the Workers' Assistance Fund (Fundo de Amparo ao Trabalhador [FAT])

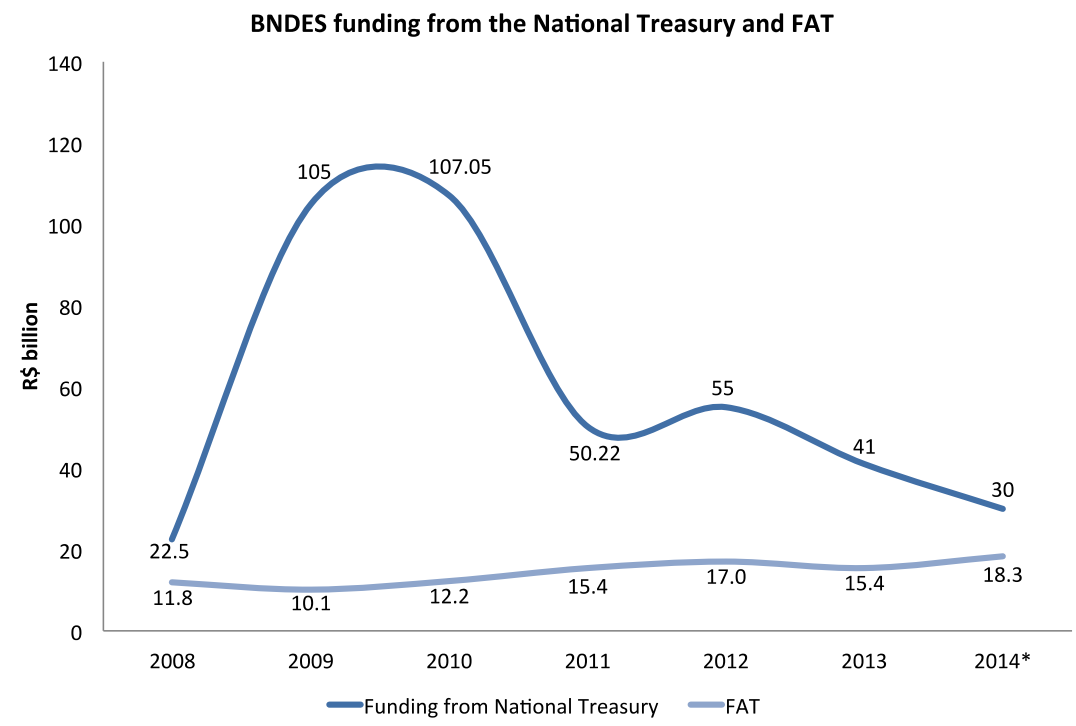

Source: BNDES

In Brazil, since the onset of the crisis, public banks play three basic roles:

- Act as a counter cyclical policy tool;

- Provide financing for developing to enhance productivity growth, support for socioeconomic infrastructure, and knowledge-specific activities; and

- Promote the development of organized liquid capital markets. 
The expansion of public banks' balance sheets allowed policymakers to counter financial instability by sharply expanding credit growth when private sector (domestic and foreign) banks reduced bank lending (Figures 3 and 4).

Figure 3 Counter-cyclical Lending Stabilized the System

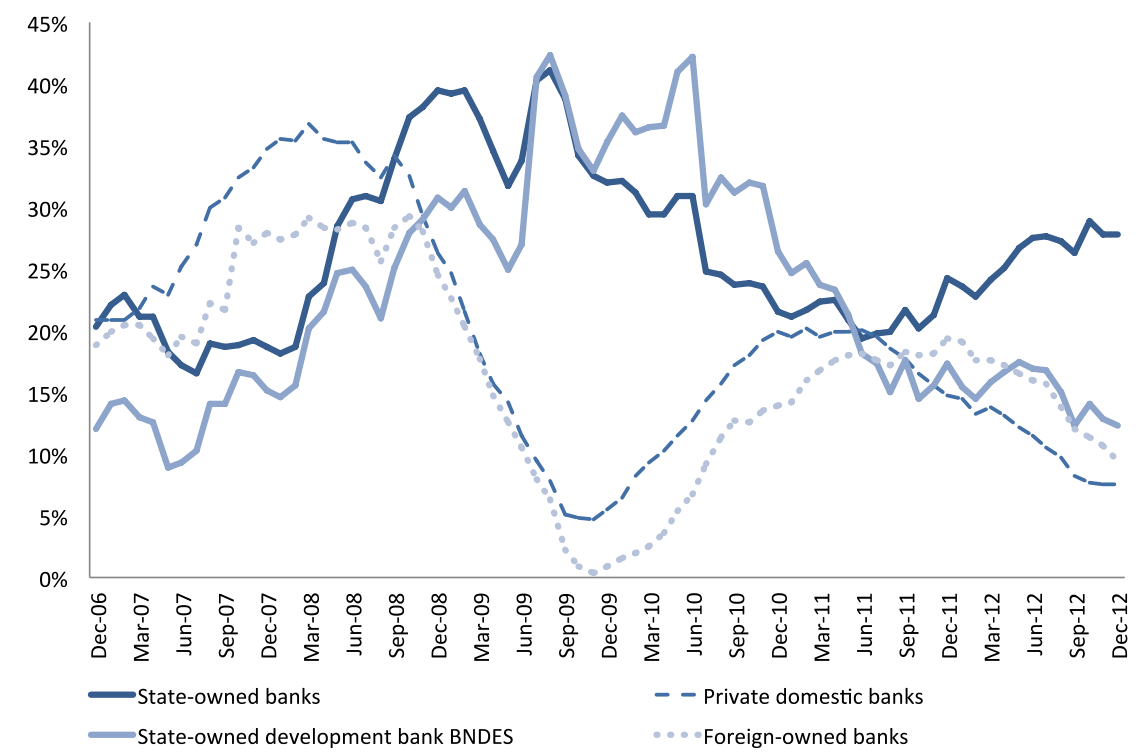

Source: $\mathrm{BCB}$

Figure 4 BNDES Disbursements

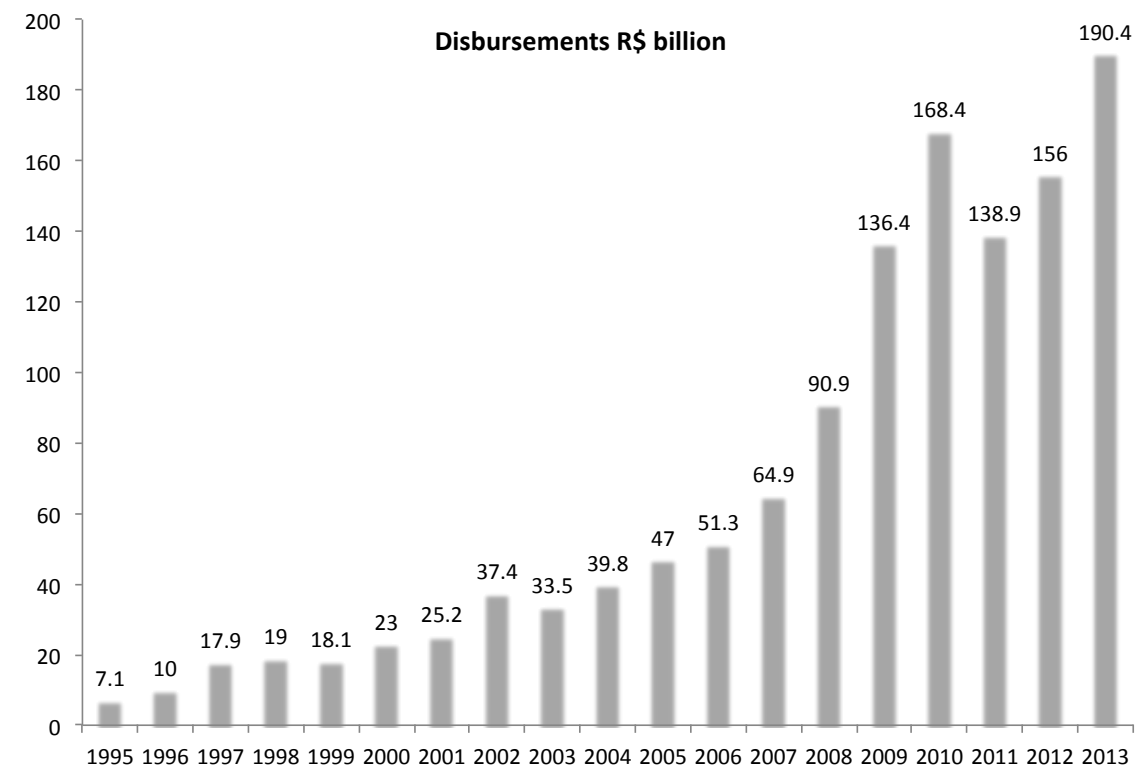

Source: BNDES 
However, BNDES has been subject to a range of criticisms. The bank's critics make the following complaints:

- BNDES "crowds out" corporate lending by private sector banks; BNDES loans provided at subsidized rates generate unfair competition with private banks due to BNDES's funding structure (Wheatley 2013);

- BNDES is curbing the development of the financial sector;

- the bank has grown too big too fast, emergency countercyclical policies implemented have gone on for too long (Forero 2013); and

- Loans from the National Treasury increase gross domestic debt and it contributes to the weakening of Brazil's sovereign's financial profile, deteriorating the National Treasury fiscal performance, and to a rise in the government's debt burden.

Much of the policy discussion has been misplaced. The critics ignore the historical role national development banks play in fostering development at different stages of economic growth (UNCTAD 2013, p. 133-134). Even though Brazil's banking sector has roughly doubled its lending as a share of GDP, the balance sheet profile of public and private banks reinforces the role of BNDES in promoting economic development through financing of long-term capital assets. It is ironic that critics say that "large companies have access to financial and capital markets, in Brazil and abroad" (Musacchio \& Lazzarini 2014) to downplay BNDES's role in providing funding for development when the costs of funds raised locally are substantially higher than the rate BNDES charges on its loans and funds raised abroad contribute significantly to external vulnerability.

It is not surprising that economists often forget history. In the past, Brazil's increased external debt levels raised the country's vulnerabilities to changes in external conditions. Against this background, BNDES plays a significant role in reducing external risk and external funding shocks - one of the root causes of the debt crisis among developing countries in the 1980s, followed by the so-called "lost decade"-by reducing firms' reliance on foreign markets as firms' liabilities can be locally funded. The bank could be criticized for not doing enough in particular for Brazil's total investment infrastructure and innovation (figures 5 and 6). Despite its growing investments in infrastructure, it is still small relative to Brazil's infrastructure investment needs. In 2013, 33\% of BNDES total disbursements were toward infrastructure investment. 
Figure 5 Disbursements by Sector

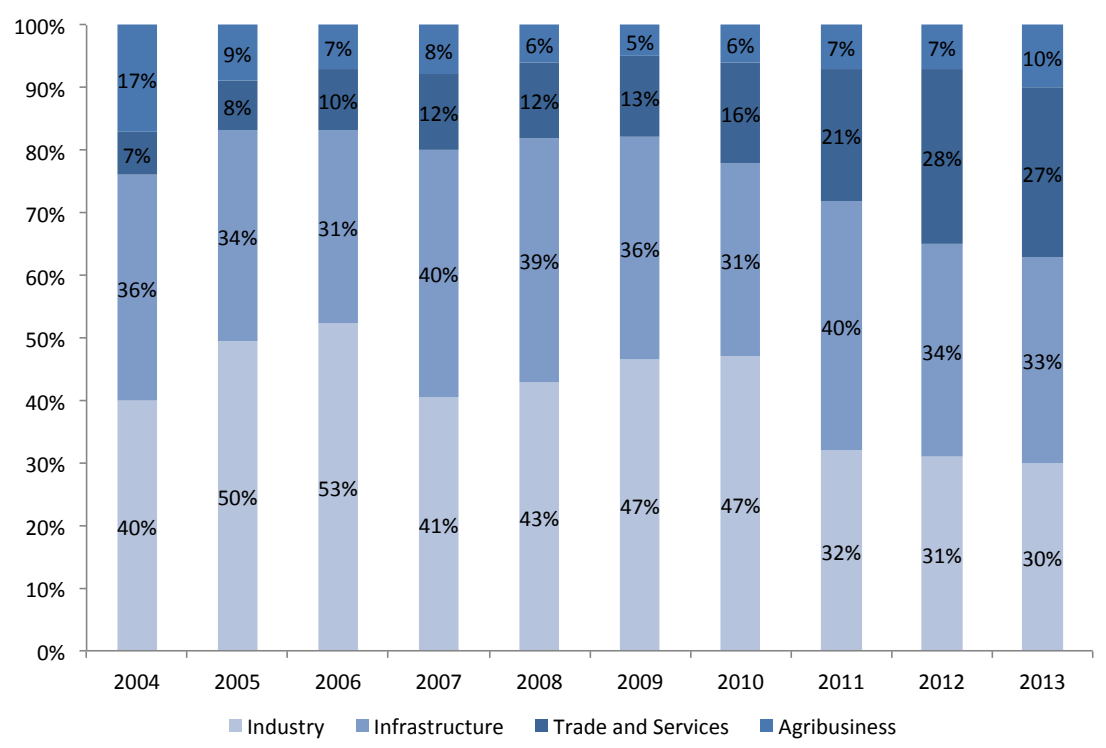

Source: BNDES

Figure 6 Federal Government Support of Innovation ${ }^{2}$ (Current R\$)

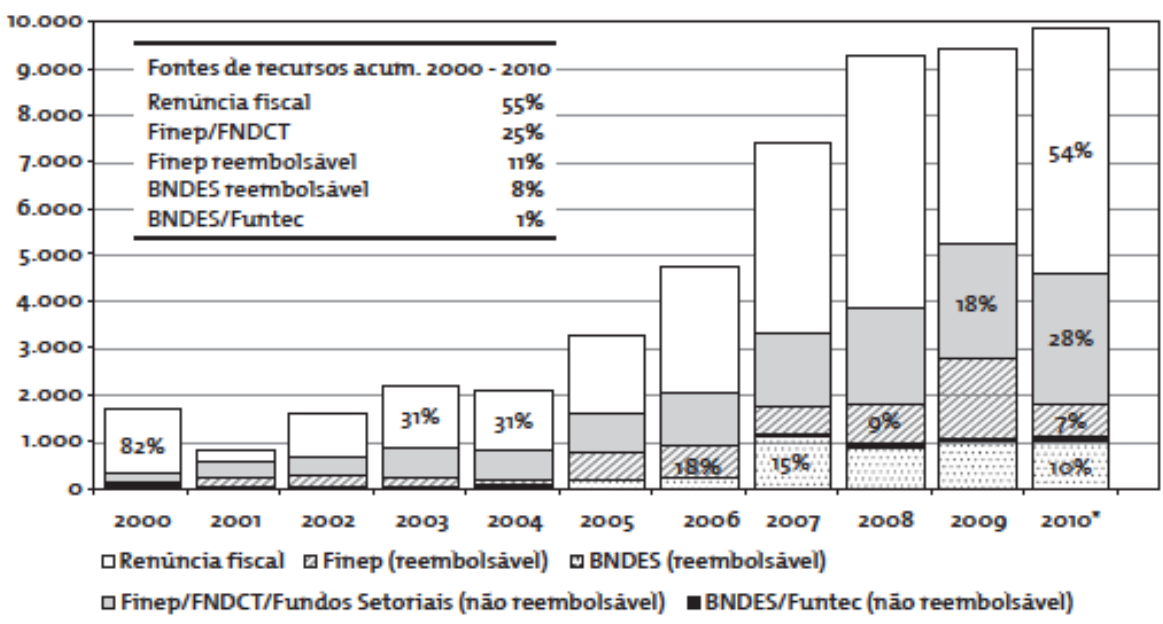

Source: Delgado 2012, p. 155

For instance, the background document of the Financing for Development Office of The United Nations Department of Economic and Social Affairs (UN-DESA) noted that "from the time when the China Development bank was established in 1994 to the end of 2005, nearly $90 \%$ of its lending was directed towards infrastructure in eight key industries - power, road construction, railway, petro- chemical, coal mining, telecommunications, public facilities, and

${ }^{2}$ Financiadora de Estudos e Projetos (FINEP), the Brazilian Agency for Innovation. FNDCT: National Fund for Scientific and Technological Development; BNDES -FUNTEC: university-industry cooperation fund. 
agriculture" (United Nations, 2005, 16). President Dilma Rousseff acknowledged "Brazil is 'two centuries' behind when it comes to building its rail network” (Leahy 2013). Brazil's transport and logistics networks face many challenges. In an attempt to boost investment, Brazil has introduced a series of policy initiatives such as the Growth Acceleration Programme (PAC 1 and 2), the BNDES Investment Maintenance Program (BNDES's PSI), the National Plan for Transport Logistics (PNLT), and it is offering public concessions to the private sector in three key areas: logistics including roads, railway, ports and airports; energy; and oil and gas. According to Brazil's finance minister, expected investments equal a total USD \$235 billion over the coming years (Table 1).

Table 1 Concessions Program Estimated Investment

\begin{tabular}{|l|c}
\hline \multicolumn{1}{|c|}{ Concessions Program } & Estimated Total Investment (US\$ billion) \\
\hline Logistics & 121 \\
\hline Roads & 21 \\
\hline Railways & 45.5 \\
\hline Ports & 27.3 \\
\hline High Speed Train & 17.8 \\
\hline Airports & 9.4 \\
\hline Energy & 74 \\
\hline Hydro & 39.9 \\
\hline Wind, Biomass, and Small Hydro & 19 \\
\hline Thermal & 1.4 \\
\hline Distribution & 13.7 \\
\hline Oil \& Gas & 40 \\
\hline Total & $\mathbf{2 3 5}$ \\
\hline
\end{tabular}

Source: Ministry of Finance

Though it is commonly believed that BNDES led to the crowding-out of debt markets from corporate financing, and private banks from long-term financing loans, because the rate it charges on its loans to firms is less than the central bank's benchmark SELIC (Special System of Clearance and Custody) overnight interest rate, the short termism in Brazil's financial market is primarily due to a high and volatile SELIC rate. During the new millenium, Brazilian banks enjoyed a great situation by holding high-quality, high-yield, short-term assets. Due to Brazil's consistently high benchmark SELIC rate, the full risk-adjusted return on liquid assets more than offset the full return on less liquid assets, such as consumer and business loans. It shifted banks' portfolio composition towards high-quality short-term liquid government securities holdings and other high-yield, low-duration assets on banks' balance sheets. Moreover, corporate lending by private banks is expensive, so funding capital expenditure from private banks is not an option 
and its high cost deters investment in capital assets. This period was characterized by large holdings of government securities on banks' balance sheets and low exposure to traditional loan products. According to central bank data, as of August 2014, state-controlled banks are responsible for $53 \%$ of outstanding loans in Brazil while the share of local private-sector banks decreased to $32 \%$, as they have sharply reduced loan origination over the past few years. ${ }^{3}$ Even though banks increased claims on the private sector as the central bank lowered its benchmark rate to record lows and have roughly doubled their lending as a share of GDP, the supply of long-term credit by private institutions remained low (Table 4).

Though it has been argued that Brazil's private-sector banks cannot compete with BNDES's below-market rates for long-term investments, much of the policy discussion has been misplaced, missing the fact that Brazilian banks operate with extremely high interest rate spreads, high operating and loan expenses, low leverage ratios, and generate high returns on equity (Table 3). The spread between short-term lending rates and commercial banks' funding costs for business and consumer loans is substantially higher relative to long-term financing activities. High returns on government securities combined with abnormally high loan spreads on short-term loan products generate extremely high returns on equity for private banks. The risk-adjusted spread of short-term loans is greater than the risk-adjusted total returns of financing long-term assets. As a result, Brazil's banking sector shifted its portfolio preferences towards high-yield, short-term assets and generates high returns on equity with low leverage compared to international peers. BNDES's competitive advantage is not due to its funding structure but it is primarily because it operates with low loan spreads (for direct lending operations, the BNDES spread is equal to its financial funding costs plus its return and a risk premium, as opposed to traditional private banks, which operate with extremely high loan spreads, high operational costs, low leverage, and high delinquency rates to generate high ROE (tables 3 and 4).

\footnotetext{
${ }^{3}$ As of September 2014, the five largest Brazilian banks by asset volume were: Banco do Brasil (BB- State-owned), Itau, Caixa Economica Federal (CEF- State-owned), Bradesco, and BNDES. The five had total assets close to US $\$ 2$ trillion, equivalent to $71 \%$ of total banking assets.
} 
Table 2 BNDES and Multilateral Agencies

\begin{tabular}{|c|c|c|c|c|}
\hline \multicolumn{5}{|c}{ BNDES vs. Multilateral Agencies } \\
\hline & BNDES & $\begin{array}{c}\text { Inter-American } \\
\text { Development Bank }\end{array}$ & $\begin{array}{c}\text { World } \\
\text { Bank }\end{array}$ & $\begin{array}{c}\text { China Development } \\
\text { Bank }\end{array}$ \\
\hline (US\$ million) & June/2014 & June/2014 & June/2014 & Dec/2013 \\
\hline \multicolumn{5}{|c|}{} \\
\hline Total Assets & 369,745 & 99,454 & 324,367 & $1,352,450$ \\
\hline Equity & 33,658 & 24,022 & 39,523 & 92,828 \\
\hline Net Income & 2,484 & 235 & 218 & 13,197 \\
\hline Disbursement & 26,697 & 3,014 & 16,03 & /A \\
\hline Capitalization (\%) & 9.1 & 24.2 & 12.2 & 6.9 \\
\hline ROA (\%) & 0.7 & 0.2 & 0.1 & 1 \\
\hline ROE (\%) & 8.5 & 1 & 0.6 & 15.1 \\
\hline
\end{tabular}

Source: BNDES financial disclosure, June 2014

Although the conventional approach believes that Brazil's financial system lacks saving and financial instruments to foster long-term investment, the primary difficulty in fostering long-term funding among private sector banks is the unattractiveness of long-term lending relative to other short-term loan products, which generate abnormally high loan spreads for consumer loans, such as payroll deductible loans, auto loans, and loans to firms, such as working capital loans, and SME loans. From this perspective, high short-term loan spreads distort credit markets. Moreover, privately owned banks have little interest in expanding their long-term loan business portfolios to provide long-term financing. Private domestic banks need competition from state-owned banks to make them more efficient. The Brazilian financial system does not lack funding mechanisms, but the difficulty is the high level and volatility of interest rates and the unattractiveness of low-risk adjusted returns on long-term assets relative to other high-yield, short-term loan segments in the presence of low-leveraged bank balance sheets, which dampens the development of a long-term credit market. Hence, domestic private banks have little interest in expanding their long-term loan business portfolios to provide longterm financing. 
Table 3 Key Profitability Indicators

\begin{tabular}{|c|c|c|c|c|c|c|c|c|c|}
\hline \multicolumn{10}{|c|}{ Profitability } \\
\hline & BNDES & BB & CEF & ITAU & BRADESCO & $\begin{array}{c}\text { WORLD } \\
\text { BANK }\end{array}$ & IADB & KFW & $\begin{array}{c}\text { CHINA } \\
\text { DB }\end{array}$ \\
\hline Return on Equity (average) (ROE) (\% p.a.) & 14.5 & 23.4 & 22.3 & 16.2 & 17 & 0.6 & 5.9 & 3.8 & 13.4 \\
\hline Net income ( $R \$$ billion $)$ & 8.2 & 16 & 6.7 & 13.9 & 12 & 0.5 & 2.9 & 2 & 19.8 \\
\hline Average equity $(\mathrm{R} \$$ bi) & 56.4 & 68.4 & 30.2 & 85.9 & 70.7 & 80.7 & 48.5 & 52 & 147.4 \\
\hline Return on Assets (average) (ROA) (\% p.a.) & 1.1 & 1.4 & 0.9 & 1.4 & 1.6 & 0.1 & 1.4 & 0.1 & 0.9 \\
\hline Total Assets ( $\mathrm{R} \$$ billion) & 781 & 1219 & 858 & 1027 & 777 & 719 & 227 & 1517 & 2465 \\
\hline Total Average Assets ( $\mathrm{R} \$$ billion) & 747 & 1153 & 781 & 989 & 766 & 702 & 207 & 1430 & 2155 \\
\hline Average Leverage & 13.3 & 16.8 & 25.8 & 11.5 & 10.8 & 8.7 & 4.3 & 27.5 & 14.6 \\
\hline Basil Ratio (\%) & 18.7 & 14.5 & 15.1 & 16.5 & 16.6 & N.A. & N.A. & N.A. & N.A. \\
\hline $\begin{array}{l}\text { Gross Interest Margin (Gross income from financial } \\
\text { intermediation / Average Fixed Income Portfolio) (\% p.a.) }\end{array}$ & $2.0 \%$ & $2.6 \%$ & $2.6 \%$ & $3.6 \%$ & $3.0 \%$ & $0.7 \%$ & $1.9 \%$ & $-0.2 \%$ & $2.3 \%$ \\
\hline Gross Income from financial intermediation ( $\mathrm{R} \$$ billion) & 12.5 & 25 & 19.2 & 28.3 & 19.5 & 4.8 & 4 & -2.3 & 49.9 \\
\hline $\begin{array}{l}\text { Gross Income (excluding allowance for credit risk) (Gross } \\
\text { income from financial intermediation excluding allowance for } \\
\text { credit risk / Average Fixed Income Portfolio) } \\
\text { (\% p.a.) }\end{array}$ & $1.9 \%$ & $4.2 \%$ & $3.9 \%$ & $6.0 \%$ & $5.1 \%$ & $0.7 \%$ & $2.0 \%$ & $-0.2 \%$ & $2.3 \%$ \\
\hline $\begin{array}{l}\text { Gross Income from financial intermediation (excluding allowance for } \\
\text { credit risk) ( } \mathrm{R} \$ \text { billion) }\end{array}$ & 11.7 & 41.1 & 28.4 & 46.8 & 32.9 & 4.8 & 4.1 & -2.3 & 49 \\
\hline
\end{tabular}

Table 4 Loans and Onlendings Portfolio

\begin{tabular}{|c|c|c|c|c|c|c|c|c|c|}
\hline \multicolumn{10}{|c|}{ Loans and Onlendings Portfolio } \\
\hline & BNDES & BB & CEF & ITAU & BRADESCO & $\begin{array}{l}\text { WORLD } \\
\text { BANK }\end{array}$ & \begin{tabular}{|c|} 
Inter-American \\
Development \\
Bank (IADB) \\
\end{tabular} & \begin{tabular}{|c} 
Kreditanstalt für \\
Wiederaufbau \\
(KFW)
\end{tabular} & \begin{tabular}{|c} 
China \\
Development \\
Bank
\end{tabular} \\
\hline $\begin{array}{l}\text { Net Portfolio (after allowance for credit } \\
\text { risk) / Total Assets (\%) }\end{array}$ & 72.4 & 53.7 & 66.3 & 39.3 & 42 & 43.8 & 72.6 & 85 & 90 \\
\hline Net Portfolio ( $\mathrm{R} \$$ billion) & 565 & 655 & 569 & 403 & 326 & 315 & 165 & 1290 & 2219 \\
\hline $\begin{array}{l}\text { Average Fixed Income Portfolio (Credit and } \\
\text { Treasury) ( } \mathrm{R} \$ \text { billion) }\end{array}$ & 624 & 980 & 731 & 778 & 641 & 730 & 206 & 1430 & 2205 \\
\hline $\begin{array}{l}\text { Long Term Credit Operations / Gross } \\
\text { Portfolio (\%) }\end{array}$ & 80.8 & 61.9 & 75.5 & 43.6 & 46.2 & 96.5 & 92.8 & N.A. & 89.6 \\
\hline $\begin{array}{l}\text { Rating AA-C Credit Operations I } \\
\text { Portfolio (\%) }\end{array}$ & 99.7 & 95 & 92.8 & 91.9 & 92.2 & N.A. & N.A. & N.A. & N.A. \\
\hline $\begin{array}{l}\text { Non-performing balance / Gross } \\
\text { Portfolio }(\%)\end{array}$ & 0.01 & 1.13 & 1.36 & 2.71 & 2.52 & N.A. & N.A. & N.A. & N.A \\
\hline
\end{tabular}

Notes:

* Sources: Bacen-Top 50 Reports and

Financial Demonstrations.

Informations from the years ended on

12/31/2012 (CDB).

* Long Term Credit Operations: >1 year

Source: BNDES financial disclosure, June 2014 


\section{Policy Alternatives to Promote Long-term Financing}

As noted earlier, for the past six years, policy makers relied on the expansion of BNDES's balance sheet through National Treasury loans and infusions of capital to fund private sector investment projects. In this regard, the composition of its liabilities changed significantly and the treasury is currently its major source of funding (Table 5).

Table 5 BNDES Balance Sheet

\begin{tabular}{|c|c|c|c|c|c|c|}
\hline & & & & & & billion \\
\hline & 2014 & $\%$ & 2013 & 2012 & 2011 & 2010 \\
\hline Cash & 2.7 & $0.3 \%$ & 0.5 & 10.3 & 5.4 & 10.1 \\
\hline Loans & 588.3 & $72.2 \%$ & 565.2 & 492.1 & 425.5 & 361.6 \\
\hline Equity Investments ${ }^{1}$ & 82.4 & $10.1 \%$ & 85.8 & 94.4 & 99.6 & 107.5 \\
\hline Securities & 98.3 & $12.1 \%$ & 91 & 86.5 & 73.9 & 50 \\
\hline Others & 42.6 & $5.2 \%$ & 39.5 & 32.3 & 20.4 & 19.8 \\
\hline Total Assets & 814.3 & $100.0 \%$ & 782 & 715.6 & 624.8 & 549 \\
\hline FAT & 192.4 & $23.6 \%$ & 176.2 & 161.9 & 146.3 & 132.3 \\
\hline PIS/PASEP & 33.6 & $4.1 \%$ & 33.6 & 32.8 & 31.7 & 30.8 \\
\hline National Treasury & 433.2 & $53.2 \%$ & 413.2 & 376 & 310.8 & 253.1 \\
\hline International Borrowings & 34.7 & $4.3 \%$ & 31.2 & 23.3 & 22.4 & 19.8 \\
\hline Others & 46.3 & $5.7 \%$ & 67.1 & 69.4 & 52.6 & 47.2 \\
\hline Shareholdes Equity & 74.1 & $9.1 \%$ & 60.7 & 52.2 & 61 & 65.9 \\
\hline Total Liabilities & 814.3 & $100.0 \%$ & 782 & 715.6 & 624.8 & 549 \\
\hline
\end{tabular}

${ }^{1}$ Equity investments in associated and non-associated companies. Since 2010, the investments in non associated companies are adjusted for fair value.

Source: BNDES financial disclosure June-2014

BNDES's balance sheet has expanded primarily due to treasury loans to BNDES, which, as of 2014, represent 53.2\% of its liabilities. In Brazil, provisional measures subsequently transformed into law authorize domestic on-lendings to BNDES from the National Treasury in which the latter issues securities through direct placement to BNDES. This transaction involves the creation of assets for the National Treasury (claims on BNDES) and the corresponding issuance of liabilities - government securities - by the National Treasury. For BNDES, their liabilities increase by the amount of the transfer of securities it holds as assets. This transaction is recorded as an electronic book entry and the net effect on the public debt is zero, though gross debt goes up by the amount of the government securities issued. However, this policy raised several criticisms due to the increase in gross public debt caused by the direct issuance of securities to BNDES. 
Figure 7 Public Sector Gross and Net Debt as a Percentage of GDP

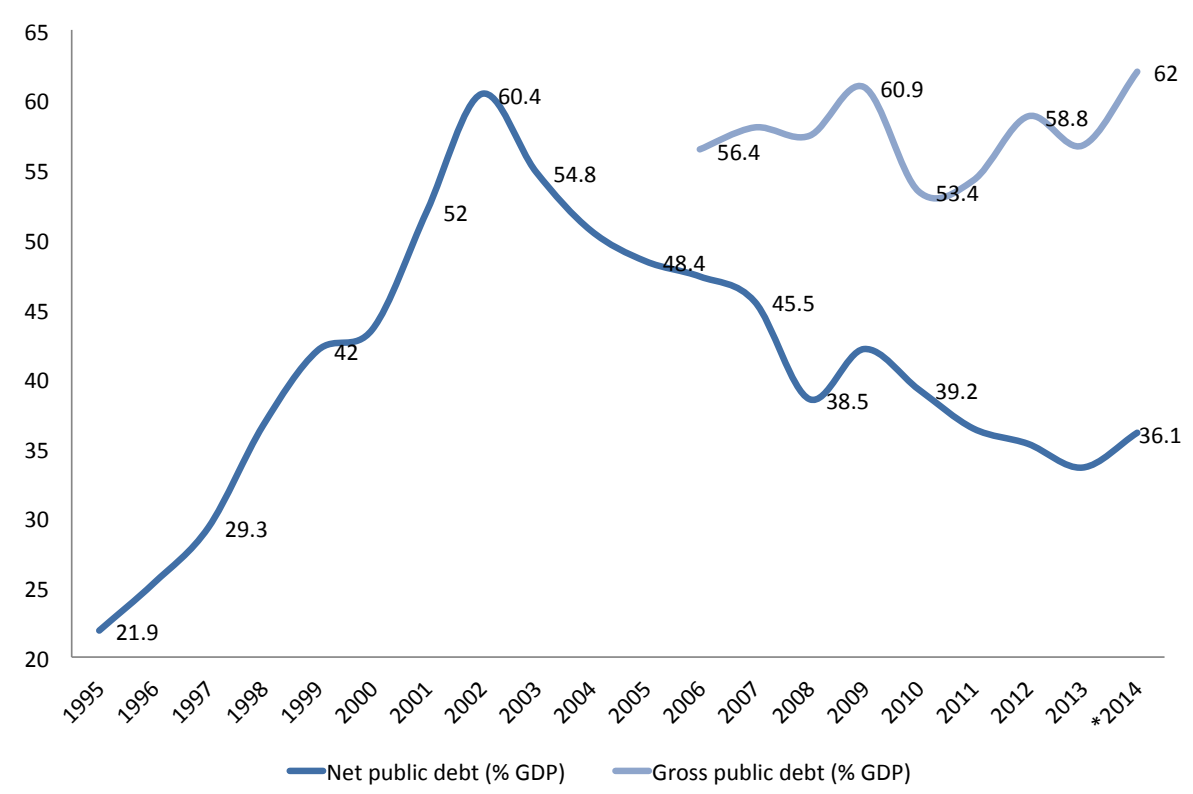

Source: Brazilian Central Bank

For this reason, much of the recent discussion about BNDES's role centers around the fiscal costs associated with National Treasury loans to BNDES - which sharply increased since 2009 - focusing on whether it produces a net cost or a net gain for the federal government (Garcia 2011b). Moreover, critics point to the negative carry operation for the treasury as the costs associated with government securities are higher than the TJLP, that is, the rate the Treasury charges on its loans to BNDES. Finally, funding from the National Treasury has been criticized on various grounds such as "dangerous creative accounting," "accounting gimmicks," "discredited fiscal accounting," and "sequence of assaults on our public accounts" (Garcia 2010).

Though critics of BNDES's balance sheet expansion point to increasing fiscal risk, they fail to understand that the federal government spends by crediting bank accounts and taxes by debiting them. Government expenditures increase reserves in the banking system. The federal government is the only net supplier of reserves, so that when they spend, there is an injection of reserves in the banking system and when taxes are collected reserves are destroyed. As we have argued elsewhere (Rezende 2009), excess reserves tend to put a downward pressure on the SELIC rate, which triggers the sale of government securities to remove those excess reserves and keep the SELIC rate close to its target. Fiscal operations lead to credits to bank accounts at 
the Brazilian central bank. As long as the Brazilian central bank operates with a positive SELIC rate target, it must intervene in the market to maintain the SELIC rate close to the target.

\section{Funding Options for BNDES}

By using a basic system of accounting in which for every financial asset there is a corresponding liability, we can evaluate and simulate the existing and alternative funding options for BNDES. We can analyze the following alternatives: a) loans from the National Treasury at TJLP to BNDES; b) loans from the Brazilian Central Bank; c) credit to BNDES's reserve account at the central bank using the National Treasury account with the $\mathrm{BCB}$; and d) BNDES issuance of bonds.

\section{a) Loans from the National Treasury to BNDES}

In its current form, loans from the National Treasury at TJLP (the long-term interest rate) to BNDES are extended through direct placement of government securities to BNDES, which then sells government securities on its portfolio as needed to increase its disbursements to provide long-term credit. As BNDES sells government securities on its portfolio, its reserve account balance with the central bank goes up. As it extends new loans to the private sector, its reserve balance goes down by the amount of the loan, and its loan portfolio increases. This transaction is equivalent to a swap of assets on BNDES's balance sheet. The loan beneficiary's bank account balance goes up and there is a corresponding increase in reserve balances on the borrowers' bank. Note that the increase in reserve balances will put a downward pressure on the overnight lending rate, triggering the intervention of the central bank through bond sales to remove excess reserves from the banking system and keep the SELIC rate close to its target. 
Figure 1: Loans from the National Treasury at TJLP to BNDES

National Treasury

\begin{tabular}{|c|c|c|c|}
\hline Assets & Liabilities & Assets & Liabilities \\
\hline + Claims on BNDES & + Government Securities & + Government Securities & + National Treasury Loans \\
\hline
\end{tabular}

BNDES sells government securities on its portfolio increasing its balances at the Central Bank Account BNDES

\begin{tabular}{|c|c|c|c|}
\hline Assets & Liabilities & Assets & Liabilities \\
\hline $\begin{array}{c}\text { - Government Securities } \\
+ \text { Balance at } \\
\text { the Central Bank }\end{array}$ & & + Reserve Balances owed to \\
BNDES \\
- Reserves owed to bank
\end{tabular}

\begin{tabular}{|c|c|}
\multicolumn{2}{c}{ Bank } \\
\hline Assets & Liabilities \\
\hline - Reserves & \\
+ Government Securities &
\end{tabular}

BNDES extends loans to the private sector

BNDES

\begin{tabular}{|c|c|}
\hline Assets & Liabilities \\
\hline $\begin{array}{c}\text { - Balance at } \\
\text { the Central Bank } \\
\text { + claims on the private sector }\end{array}$ & \\
\hline
\end{tabular}

\section{Bank}

\begin{tabular}{|c|c|}
\hline Assets & Liabilities \\
\hline $\begin{array}{c}\text { + Reserve Balances at } \\
\text { the Central Bank }\end{array}$ & $\begin{array}{c}\text { + Deposits owed to the } \\
\text { non-bank private sector }\end{array}$ \\
\hline
\end{tabular}

Central Bank

\begin{tabular}{|c|c|}
\hline Assets & Liabilities \\
\hline & $\begin{array}{c}\text { - Balance owed to BNDES } \\
+ \text { Reserve Balances owed to } \\
\text { bank }\end{array}$ \\
\hline
\end{tabular}

Non-Bank Private Sector

\begin{tabular}{|c|c|}
\hline Assets & Liabilities \\
\hline + Deposits at bank & +Loans owed to BNDES \\
& \\
\hline
\end{tabular}

BCB sells bonds from its portfolio to remove the excess reserves Bank

\begin{tabular}{|c|c|c|c|}
\hline Assets & Liabilities & Assets & Liabilities \\
\hline $\begin{array}{c}\text { - Reserve Balances at } \\
\text { the Central Bank } \\
\text { + Government Securities }\end{array}$ & & - Government Securities & - Reserves owed to bank \\
\hline
\end{tabular}

BNDES

\begin{tabular}{|c|c|}
\hline Assets & Liabilities \\
\hline + claims on the private sector & + National Treasury Loans \\
\hline
\end{tabular}

National Treasury

\begin{tabular}{|c|c|}
\hline Assets & Liabilities \\
\hline + Claims on BNDES & + Government Securities \\
\hline
\end{tabular}

Non-Bank Private Sector

\begin{tabular}{|c|c|}
\hline Assets & Liabilities \\
\hline + Deposits at bank & +Loans owed to BNDES \\
\hline
\end{tabular}

Bank

\begin{tabular}{|c|c|}
\hline Assets & Liabilities \\
\hline + Government Securities & $\begin{array}{l}\text { + Deposits owed to the } \\
\text { non-bank private sector }\end{array}$ \\
\hline
\end{tabular}


So, the final position for each unit is the following: BNDES has an asset (the loan) matched by a liability (loans from the National Treasury); the borrowers' bank holds government securities as assets and deposits as liabilities; the borrower has increased its liabilities by the amount of the loan from BNDES and its deposit balance has increased by the amount of the loan. On the consolidated balance sheet of the government, its asset increased by the amount of claims of the private sector by issuing liabilities (government securities).

\section{b) Loans from $B C B$ at TJLP}

Since last June, BNDES has had direct access to Brazil's payment system (SPB) and it has a reserve account at the central bank to settle payments and transactions. This initiative creates the possibility to provide alternative sources of funding for BNDES. An alternative approach would be to allow the central bank to credit BNDES's reserve account. This funding option is not radically new.

Historically, central banks have used a wide variety of instruments to channel long-term finance in support of development objectives, including direct financing of non-financial firms... Central bank and government intervention in credit allocation became widespread in the immediate post-war period in developed and developing countries alike (UNCTAD 2013, p.133-134).

In this way, BNDES's assets would go up by the same amount and its liabilities (borrowings from the central bank) would go up by the amount of the loan. It would allow BNDES to engage in direct lending and would also allow the maturity transformation inside the banking system. By extending loans, BNDES would increase its credit portfolio and its reserve balance with the central bank would go down. On the other hand, the bank's account balance with the central bank increases, matched by an increase in its deposit liabilities. The loan recipient's account balance at its bank would go up, matched by an increase in its liabilities (loans from BNDES). This increase in reserve balances at depository institutions puts a downward pressure on the SELIC rate and triggers the sale by the central bank of government securities to drain reserve balances from the banking system to keep the SELIC rate close to its target. This transaction is an asset swap of central bank liabilities for government securities. 
Figure 2: Loans from BCB

\begin{tabular}{|c|c|}
\hline \multicolumn{1}{|c|}{ BNDES } & Liabilities \\
\hline $\begin{array}{c}\text { Assets } \\
\text { + Reserve Balances at } \\
\text { the central Bank }\end{array}$ & + Borrowed Res
\end{tabular} \mid \begin{tabular}{c|c|} 
Assets & Liabilities \\
\hline
\end{tabular}

BNDES extends loans

BNDES

\begin{tabular}{|c|}
\hline Assets \\
\hline $\begin{array}{c}\text { - Reserve Balances at } \\
\text { the central Bank } \\
\text { +Claims on the private sector }\end{array}$
\end{tabular}

Bank

\begin{tabular}{|c|c|}
\hline Assets & Liabilities \\
\hline $\begin{array}{c}\text { + Reserve Balances at } \\
\text { the Central Bank }\end{array}$ & $\begin{array}{c}\text { + Deposits owed to the } \\
\text { non-bank private sector }\end{array}$ \\
\hline
\end{tabular}

Non-Bank Private Sector

\begin{tabular}{|c|c|}
\hline Assets & Liabilities \\
\hline + Deposits at bank & +Loans owed to BNDES \\
& \\
\hline
\end{tabular}

Central Bank

\begin{tabular}{|c|c|}
\hline Assets & Liabilities \\
\hline & $\begin{array}{c}\text { - Balance owed to BNDES } \\
\text { + Reserve Balances owed to } \\
\text { bank }\end{array}$ \\
\hline
\end{tabular}

$\mathrm{BCB}$ sells bonds from its portfolio to remove the excess reserves Bank

\begin{tabular}{|c|c|c|c|c|}
\hline \multicolumn{2}{|c|}{ Bank } & Liabilities & Assets & Liabilities \\
\hline $\begin{array}{c}\text { - Reserve Balances at } \\
\text { the Central Bank } \\
\text { + Government Securities }\end{array}$ & & - Government Securities & - Reserves owed to bank \\
\hline
\end{tabular}

Final Position

\begin{tabular}{|c|c|}
\hline \multicolumn{2}{|c|}{ BNDES } \\
\hline Assets & Liabilities \\
\hline + claims on the private sector & + Borrowed Res \\
\hline
\end{tabular}

\begin{tabular}{|c|c|}
\hline \multicolumn{2}{|c|}{ Central Bank } \\
\hline Assets & Liabilities \\
\hline + Claims on BNDES & \\
- Government Securities &
\end{tabular}

Banks

\begin{tabular}{|c|c|}
\hline Assets & Liabilities \\
\hline + Government Securities & $\begin{array}{l}\text { + Deposits owed to the } \\
\text { non-bank private sector }\end{array}$ \\
\hline
\end{tabular}

Non-Bank Private Sector

\begin{tabular}{|c|c|}
\hline Assets & Liabilities \\
\hline + Deposits & +Loans owed to BNDES \\
\hline
\end{tabular}

Note that on the consolidated balance sheet of the government it has an asset—claims on the private sector-matched by an increase in its liabilities (borrowed reserves).

\section{c) Credit BNDES's Reserve Account at the Central Bank using the National Treasury Account with the $B C B$}

In this case, the National Treasury's reserve balances with the central bank go down by the amount of the loan and BNDES's balance at the central bank goes up by the same amount, matched by a corresponding increase in its liabilities. It can then extend new loans so reserve 
balances go down and its loan portfolio goes up. The borrower's account goes up and its bank reserve balances go up, adding reserves to the banking system, which will put downward pressure on the SELIC rate, triggering securities sales by the central bank.

Figure 3: Credit BNDES's reserve account at the central bank using the National Treasury account with the BCB

\begin{tabular}{|c|c|c|c|}
\hline \multicolumn{2}{|c|}{ National Treasury } & \multicolumn{2}{|c|}{ Central Bank } \\
\hline Assets & Liabilities & Assets & Liabilities \\
\hline $\begin{array}{l}\text { - Reserve Balances at } \\
\text { the Central Bank } \\
+ \text { Claims on BNDES }\end{array}$ & & & $\begin{array}{l}\text { - Reserve Balance owed to the } \\
\text { National Treasury } \\
\text { + Reserve Balances owed to } \\
\text { BNDES }\end{array}$ \\
\hline
\end{tabular}

BNDES

\begin{tabular}{|c|c|}
\hline Assets & Liabilities \\
\hline $\begin{array}{c}\text { + Reserve Balances at } \\
\text { the central Bank }\end{array}$ & + National Treasury Loans \\
\hline
\end{tabular}

\begin{tabular}{|c|c|c|c|}
\hline \multicolumn{2}{|c|}{$\begin{array}{l}\text { BNDES extends loans } \\
\text { BNDES }\end{array}$} & \multicolumn{2}{|c|}{ Non-Bank Private Sector } \\
\hline Assets & Liabilities & Assets & Liabilities \\
\hline $\begin{array}{l}\text { - Reserve Balances at } \\
\text { the central Bank } \\
\text { +Claims on the private sector }\end{array}$ & & + Deposits at bank & +Loans owed to BNDES \\
\hline \multicolumn{2}{|c|}{ Bank } & \multicolumn{2}{|c|}{ Central Bank } \\
\hline Assets & Liabilities & Assets & Liabilities \\
\hline $\begin{array}{c}\text { + Reserve Balances at } \\
\text { the Central Bank }\end{array}$ & $\begin{array}{l}\text { + Deposits owed to the } \\
\text { non-bank private sector }\end{array}$ & & $\begin{array}{l}\text { - Balance owed to BNDES } \\
\text { + Reserve Balances owed to } \\
\text { bank }\end{array}$ \\
\hline
\end{tabular}

BCB sells bonds from its portfolio to remove the excess reserves

\begin{tabular}{|c|c|c|c|}
\hline \multicolumn{2}{|c|}{ Bank } & \multicolumn{2}{|c|}{ Central Bank } \\
\hline Assets & Liabilities & Assets & Liabilities \\
\hline $\begin{array}{c}\text { - Reserve Balances at } \\
\text { the Central Bank } \\
+ \text { Government Securities }\end{array}$ & & - Government Securities & - Reserves owed to bank \\
\hline
\end{tabular}

Final Position

\begin{tabular}{|c|c|}
\hline \multicolumn{2}{|c|}{ BNDES } \\
\hline Assets & Liabilities \\
\hline + claims on the private sector & + National Treasury Loans \\
\hline
\end{tabular}

\begin{tabular}{|c|c|}
\hline \multicolumn{2}{|c|}{ Central Bank } \\
\hline Assets & Liabilities \\
\hline - Government Securities & $\begin{array}{c}\text { - Balance owed to the } \\
\text { National Treasury }\end{array}$ \\
\hline
\end{tabular}

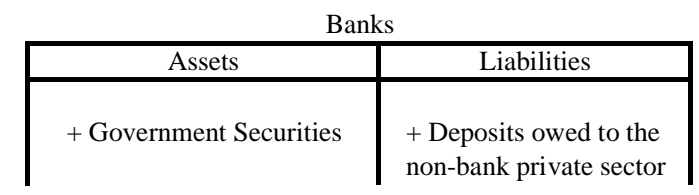

\begin{tabular}{|c|c|}
\hline \multicolumn{2}{|c|}{ Non-Bank Private Sector } \\
\hline Assets & Liabilities \\
\hline + Deposits & +Loans owed to BNDES \\
\hline
\end{tabular}

\begin{tabular}{|c|c|}
\hline \multicolumn{2}{|c|}{ National Treasury } \\
\hline Assets & Liabilities \\
\hline - Reserve Balances at \\
the Central Bank \\
+ Claims on BNDES
\end{tabular}


The final position for BNDES, the borrower, and its bank is the same as in the case in which the Treasury transfers government securities to BNDES.

\section{d) BNDES Issues Bonds Before it Can Extend New Loans}

In this case, BNDES issues bonds to raise funds to extend new loans. Its reserve balance at the central bank goes up by the amount of the bond sale.

Figure 4: BNDES issues bonds

\begin{tabular}{|c|c|c|c|}
\hline \multicolumn{2}{|c|}{ BNDES } & \multicolumn{2}{|c|}{ Central Bank } \\
\hline Assets & Liabilities & Assets & Liabilities \\
\hline $\begin{array}{c}\text { + Reserve Balances at } \\
\text { the central Bank }\end{array}$ & + Bonds & & $\begin{array}{c}\text { - Res. Balances owed to bank } \\
\text { + Reserve Balances owed to } \\
\text { BNDES }\end{array}$ \\
\hline \multicolumn{2}{|c|}{ Bank } & & \\
\hline Assets & Liabilities & & \\
\hline $\begin{array}{c}\text { - Reserve Balances at } \\
\text { the central Bank } \\
\text { + Bonds }\end{array}$ & & & \\
\hline
\end{tabular}

BNDES extends loans

\begin{tabular}{|c|c|c|c|}
\hline \multicolumn{2}{|c|}{ BNDES } & \multicolumn{2}{|c|}{ Non-Bank Private Sector } \\
\hline Assets & Liabilities & Assets & Liabilities \\
\hline $\begin{array}{c}\text { - Reserve Balances at } \\
\text { the central Bank } \\
\text { +Claims on the private sector }\end{array}$ & & + Deposits at bank & +Loans owed to BNDES \\
\hline \multicolumn{2}{|c|}{ Bank } & \multicolumn{2}{|c|}{ Central Bank } \\
\hline Assets & Liabilities & Assets & Liabilities \\
\hline $\begin{array}{c}+ \text { Reserve Balances at } \\
\text { the Central Bank }\end{array}$ & $\begin{array}{l}\text { + Deposits owed to the } \\
\text { non-bank private sector }\end{array}$ & & $\begin{array}{l}\text { - Balance owed to BNDES } \\
+ \text { Reserve Balances owed to } \\
\text { bank }\end{array}$ \\
\hline
\end{tabular}

$\mathrm{BCB}$ sells bonds from its portfolio to remove the excess reserves Bank

\begin{tabular}{|c|c|c|c|}
\hline \multicolumn{2}{|c|}{ Bank } & \multicolumn{2}{|c|}{ Central Bank } \\
\hline Assets & Liabilities & Assets & Liabilities \\
\hline $\begin{array}{c}\text { - Reserve Balances at } \\
\text { the Central Bank } \\
+ \text { Government Securities }\end{array}$ & & - Government Securities & - Reserves owed to bank \\
\hline
\end{tabular}

\begin{tabular}{|c|c|}
\hline \multicolumn{2}{|c|}{ Final Position } \\
\hline BND & \\
\hline Assets & Liabilities \\
\hline+ claims on the private sector & + Bonds \\
\hline
\end{tabular}

\begin{tabular}{|c|c|}
\hline \multicolumn{2}{|c|}{ Banks } \\
\hline Assets & Liabilities \\
\hline + Bonds & $\begin{array}{l}\text { + Deposits owed to the } \\
\text { non-bank private sector }\end{array}$ \\
\hline
\end{tabular}

\begin{tabular}{|c|c|}
\hline \multicolumn{2}{|c|}{ Non-Bank Private Sector } \\
\hline Assets & Liabilities \\
\hline + Deposits & +Loans owed to BNDES \\
\hline
\end{tabular}


Note that regardless of the funding alternative, the increase in reserve balances tends to put downward pressure on the SELIC rate, which will trigger the sale for securities to remove excess reserve balances in the system. Moreover, the final balance sheet position is the same in all those funding options: BNDES has a claim on the private sector, the National Treasury (or the central bank) has a claim on BNDES, the firm has a loan, and the bank holds government securities. Note that in the fourth case, the bank has a claim on BNDES, that is, it holds a government liability. These transactions reflect the basic principle that economic units buy assets by issuing liabilities. It reflects the endogenous money approach in which "banks 'create credit,' that is, that they create deposits in their act of lending" (Schumpeter 1954: 1080). Just like Minsky observed, economic units buy assets by issuing IOUs. For Minsky, "Banking is not money lending; to lend, a money lender must have money. The fundamental banking activity is accepting, that is, guaranteeing that some party is creditworthy" (Minsky 1986: 256).

This approach to banking sees money creation as going from banks' assets to liabilities. Banks purchase assets (such as the liabilities of borrowers, IOUs) through the issuance of liabilities (such as deposits, banks' IOUs). The federal government operates in a similar way as it buys assets (claims on the nongovernment sector) by issuing its own IOUs (either reserves or government securities). This transaction should not be seen as an accounting trick, but rather those funding options presented above represent accounting transactions with government debt (either reserves or government securities).

However, the design and reform of financing mechanisms involves a political choice about how to direct and allocate public resources. For instance, the financing agreement between the National Treasury and BNDES stipulates the costs of treasury loans tied to the TJLP, currently at 5\%, and the costs of securities issued by the Treasury is approximated by the overnight SELIC rate (Figure 8). 
Figure 8 SELIC Rate and TJLP (Long-term Interest Rate)

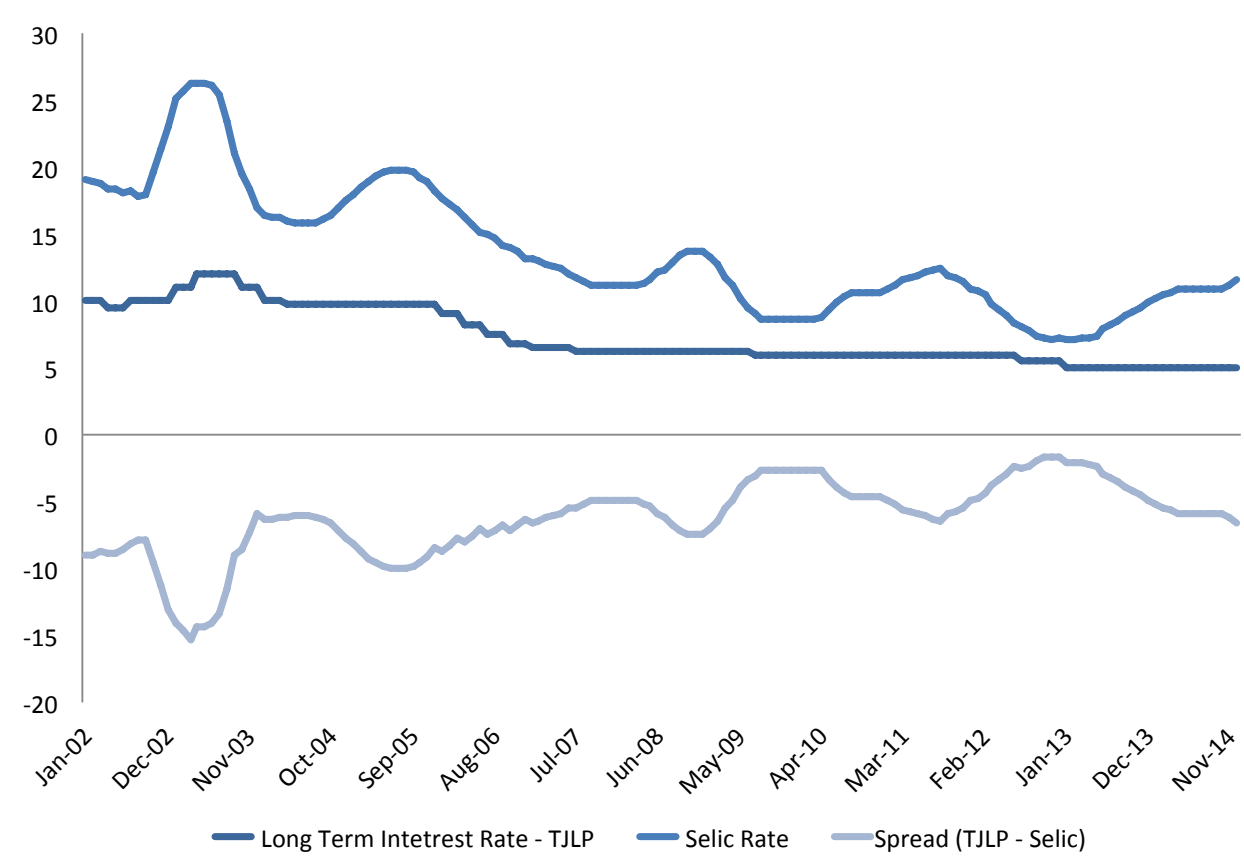

Source: BCB

Critics point to the negative carry of treasury loans represented by the difference between the SELIC rate and the long-term interest rate (TJLP). Most economists believe that in order to decrease the subsidy implicit in BNDES's loans, the TJLP should be close, if not equal, to the SELIC rate. One group argues that the government should raise (Garcia 2014) the TJLP toward the SELIC rate, while the other group suggests that the SELIC rate should fall toward the long-term rate (Romero 2014). However, the proposal to increase the TJLP would decrease the demand price of an investment project, that is, it decreases the present value of the discounted expected future cash flows of an investment project, so fewer investment projects will be more profitable relative to money. As is well known, Keynes proposed policies that would increase expected future cash flows and reduce the interest rate, thus increasing the demand price relative to the supply price of capital assets. As Keynes noted, "those assets of which the normal supply-price is less than the demand-price will be newly produced; and these will be those assets of which the marginal efficiency would be greater than the rate of interest" (Keynes, 1936, p.228). That is, an increase in the TJLP lowers the demand price relative to the supply price of capital assets, deterring investment, as investors would require higher return rates on new investment projects. 
Moreover, not only do investors have to formulate expectations about future cash flows (or future "q"s) but they have to form expectations about future interest rates which are included in the calculation of the project's net present value. This is a system in which expectations of future conditions determine present decisions. As Keynes put it, "it is by reason of the existence of durable capital equipment that the economic future is linked to the present" (Keynes 1936, p.146). Changes in the market interest rate level bring about change in the NPV of an investment project. Interest rate volatility affects the real economy through changes in the discount factor of investment decisions. Thus a high and volatile interest rate increases uncertainty associated with productive investments. From this perspective, funding from BNDES at a relatively stable long-term interest rate (TJLP) reduces the uncertainty involved in predicting changes in the future path of interest rates, considering the riskiness of each individual project.

\section{Long-term Funding Options Involving Domestic Capital Markets}

There has been much discussion about the development of longer-term private finance. Though much of the discussion agrees that a basic requirement to foster long-term funding is low interest rates, it overlooks the fact this alternative requires low and stable market interest rates. As noted earlier, banks can operationally finance long-term assets by issuing governmentinsured deposit liabilities and profit from a steep and normal-shaped yield curve. However, the financing of long-term assets by them would impose significant asset liability mismatches on banks' balance sheets. The important question is related to the costs of carrying a mismatch between the duration of assets and liabilities on bank balance sheets as long as interest and funding risks are carried on their books.

A number of policy initiatives designed to encourage local private banks and capital markets to provide funding to support long-term investment have been implemented and tailored to meet investors' needs, such as private sector long-term bonds, credit rights investment funds, infrastructure bonds, and infrastructure bonds investment funds. One of the main challenges is the creation of long-maturity instruments to be sold to investors with longtime horizons. Recent efforts by policymakers directed at lengthening the duration of bank liabilities included the development of financial bills (letras financeiras), thus imposing maturity matching on banks' books. Though it is believed that this policy initiative raises funding to finance long-term assets, it is rather an asset liability management (ALM) strategy to reduce the 
IRR on banks' balance sheets by increasing the duration of liabilities, thus reducing the mismatch between assets and liabilities.

A basic requirement for the development of long-term financing by the private sector is low and stable interest rates to induce investors to hold long-term financial assets. Though modern central banks implement policy by operating with a short-term interest rate target to influence the longer end of the yield curve, Keynes would have supported a policy to influence the entire yield curve. The central bank would announce targets for the whole yield curve and it would buy and sell securities at prices compatible with the targeted yields. ${ }^{5}$

First, by reducing interest rate volatility, the monetary authority can effectively induce financial institutions to "move out the yield curve" by targeting long-term interest rates and reducing future rate uncertainty. A basic requirement for banks' exposure to long-term fixed assets is an upward sloping yield curve and a stable interest rate environment to mitigate interest rate risk. In the presence of a stable and low yield curve, banks could ride the yield curve and raise returns. A steep treasury yield curve and the promise that short-term interest rates would remain low for an extended period would provide the basis for financial institutions to profit from a steeper yield curve. A reduction in expected rate volatility minimizes the expectation of capital losses on long-term bond positions, encouraging financial institutions to profitably ride the yield curve (Rezende 2014b). As a result, if those conditions are fulfilled, we can foresee banks lengthening the maturity of their assets. To this end, the Brazilian central bank can determine the term structure of risk-free interest rates by setting both the long-term rate and the short-term rate. Keynes (1936) correctly criticized central banks' decision to operate only in short-term debt markets:

The monetary authority often tends in practice to concentrate upon short-term debts and to leave the price of long-term debts to be influenced by belated and imperfect reactions from the price of short-term debts; - though here again there is no reason why they need do so. (Keynes 1936:206)

He goes on to say that "open-market operations have been limited to the purchase of very shortdated securities, the effect may, of course, be mainly confined to the very short-term rate of

\footnotetext{
5 Though the transmission mechanism of monetary policy by changing the overnight lending rate is supposed to have an impact on the level of economic activity by changing bank lending, this effect is uncertain and indirect. The operation of public banks by influencing bank lending has a direct and more effective impact on monetary policy's objective.
} 
interest and have but little reaction on the much more important long-term rates of interest." (Keynes 1936:197). He then concluded that:

If the monetary authority were prepared to deal both ways on specified terms in debts of all maturities, and even more so if it were prepared to deal in debts of varying degrees of risk... The complex of rates of interest would simply be an expression of the terms on which the banking system is prepared to acquire or part with debts...Perhaps a complex offer by the central bank to buy and sell at stated prices gilt-edged bonds of all maturities, in place of the single bank rate for short-term bills, is the most important practical improvement which can be made in the technique of monetary management (Keynes, 1936: 205, emphasis added).

In order to set interest rates of longer term debt, the central bank should offer interestbearing term deposits for different maturities to support longer term rates. In fact, the TreasuryFed accord created a system of pegged rates generating an upward sloping yield curve. Financial institutions sold short-term instruments, such as three-month Treasury Bills, to buy long-term instruments. This policy was so successful that it was necessary to "limit bank purchases of long-term debt" (Meltzer 2003, 591). This policy created an increase in the demand for longterm securities and "by 1945 the Federal Reserve had acquired almost all of the outstanding bills" (Meltzer 2003, 596).

In addition to low and stable interest rates to foster private sector investment in longterm assets, the policy alternatives to augment investment involve the private and the public sector, that is, the federal government could undertake investment projects itself through fiscal policy or allow BNDES to fund long-term investment activities so the private sector can undertake such projects. Though public investment has increased, it has remained low compared to Brazil's investment needs (Rezende 2014).

In Keynes's framework, the condition required to get expansion of output is to produce a situation of normal backwardation in which spot prices are below forward prices and prices of production of future commodities are below the forward price of future commodities. If spot prices are below the forward price, investors will start to buy stocks that exist because they are going to profit from holding the stocks and selling them forward. ${ }^{6}$ This will reduce the available/current supplies so that individuals can expand production of output in order to sell forward, leading to an increase in employment. The idea of normal backwardation can be seen as the motor force for expansion in the economy. The expansion of output requires changes in

\footnotetext{
${ }^{6}$ See Kregel (2010) for a detailed exposition of Keynes's contributions to the theory of finance.
} 
the spot price relative to the forward price, that is, backwardation will lead to profit incentives that will encourage individuals to invest, leading to an expansion of output through the multiplier process. In this regard, though public banks play an important role in promoting real capital development and dampening market instability, their actions must be coordinated with macro policies to keep the economy in a quasi-boom state and prevent depressions.

Keynes's economic policy views went beyond public spending as a counter-cyclical policy tool. Public sector policy, by using the fiscal powers of the federal government, should be designed to fully mobilize unexploited domestic resources. In Keynes's framework, in order to smooth the cyclical movements of employment and output, we should set the market interest rate as low as possible, so that carrying costs of holding commodities are low, and reduce excess stocks by buying existing commodities or existing capital stock. At the same time, it is necessary to shorten the time interval in which investors run off excess capacity. That is, the government has to step in as a buyer, reducing excess stocks and excess productive capacity. As government purchases increase, capacity utilization also increases, and it will reach a state in which investors will engage in replacement of investment and output expansion.

\section{CONCLUSION}

As noted earlier, banks can finance long-term assets by issuing short-term liabilities. If the current administration wants to encourage funding of long-term assets from private banks, then it could allow them to borrow at the discount window at low rates such as the TJLP to fund long-term assets. Initially, the credit line could be up to one-third of banks' equity. ${ }^{7}$ This proposal deals with potential liquidity problems due to the maturity mismatch. However, there still exists IRR on banks' balance sheets. Alternatively, banks could sell their long-term portfolio to BNDES so private banks would avoid the IRR due to the funding of long-term assets with short-term liabilities. BNDES would buy these long-term assets using reserves balances. In this regard, private banks would focus on their specialization in underwriting. On the originators' balance sheet, we would have maturity matching, that is, reserves as assets and short-term liabilities, and BNDES would hold long-term assets on its portfolio.

\footnotetext{
7 This rule is arbitrary and ultimately depends on the country's long-term investment needs, the availability of real resources, and the state of the economy.
} 


\section{References}

Barbosa, N. (2010). "Latin America: Counter-Cyclical Policy in Brazil: 2008-09," Journal of Globalization and Development, 1(1): 1-11.

Blanchard, O.J. (2009). “The State of Macro,” Annual Review of Economics 1, 1-20.

Blanchard, O.J. (2014). “Where Danger Lurks," IMF Finance \& Development, September 2014, Vol. 51, No. 3.

BNDES. (2014). BNDES Financial Disclosure, June 2014.

Delgado, V. (2012). “2000-2010: Uma Década de Apoio Federal à Inovação no Brasil," Revista do BNDES, n. 37, June 2012.

Forero, J. (2013). “A Bank that may be too Big for Brazil,” Washingtonpost.com, December 14.

Fraga, A. (2005). "General Discussion: Has Financial Development Made the World Riskier?" Proceedings from the Economic Policy Symposium - Jackson Hole, Federal Reserve Bank of Kansas City, issue Aug, pages 387-397.

Garcia, M. (2010). "Brazil: Creative Accounting and Fiscal Risk," Retrieved from http://www.economonitor.com/blog/2010/10/brazil-creative-accounting-and-fiscal-risk/. . (2011). "What Is the BNDES For?" Retrieved from http://www.economonitor.com/blog/2011/07/what-is-the-bndes-for/\#_ftn1 . (2011b). "Treasury Loans to the BNDES: Cornucopia? Retrieved from http://www.economonitor.com/blog/2011/12/treasury-loans-to-the-bndes-cornucopia/ . (2014). "Time to Wean Brazilian Companies off the BNDES.” FT.com, May 28.

Schumpeter, J.A. (1954). History of Economic Analysis. London and New York, Routledge.

Keynes, J.M. (1936). The General Theory of Employment, Interest, and Money. New York: Harcourt Brace.

Kregel J. (2014). "Minsky and Dynamic Macroprudential Regulation," PSL Quarterly Review, vol. 67 n. 269 , pp. $217-238$

Kregel, J. (2010). "Keynes Influence on Modern Economics: Some Overlooked Contributions of Keynes's Theory of Finance and Economic Policy," In B. Bateman, T. Hirai, \& M. Marcuzzo (Eds.), The Return to Keynes (pp. 241-256), Cambridge, Massachussets: Harvard.

Leahy, J. (2013). "Brazil Risks Lost Decade as it Bungles Infrastructure Boost,” FT.com, September 22. 
Meltzer, Allan H. 2003. A History of the Federal Reserve: Volume I, University of Chicago Press.

Minsky, H.P. 1986. Stabilizing an Unstable Economy, New Heaven: Yale University Press.

Musacchio, A, and Lazzarini, S. (2014) “Assessing Brazil’s BNDES,” FT.com, Jun 06.

Rezende, F.C. 2009. "The Nature of Government Finance in Brazil," International Journal of Political Economy, M.E. Sharpe, Inc., vol. 38(1), pages 81-104, April. . 2014. "Did Ms. Rousseff's Epiphany Come too Late?" Retrieved from Http://Multiplier-Effect.Org/Did-Ms-Rousseffs-Epiphany-Come-Too-Late/ . 2014b. "Demand for Financial Assets and Monetary Policy: A Restatement of the Liquidity Preference Theory and the Speculative Demand for Money," Manuscript submitted for publication.

Romero, C. 2014. "Cabe ao Governo Eleito Pelo Povo Fixar as Prioridades," Valor.com, October 22.

UNCTAD (TDR 2013). Trade and Development Report, 2013. Adjusting to the Changing Dynamics of the World Economy, United Nations publication, Sales No. E .13.II .D.3, New York and Geneva.

United Nations. (2002). "The Monterrey Consensus," International Conference on Financing for Development, Monterrey, México, March 2002.

United Nations. (2005). "Rethinking the Role of National Development Banks," Financing for Development Office of UN-DESA, New York, December 2005.

Wheatley, J. (2013). “Brazil’s BNDES: Crowding out, Not Crowding in,” FT.com, Jan. 24.

Wray, L.R. 2011. "The Dismal State of Macroeconomics and the Opportunity for a New Beginning," Working Paper no. 652, Levy Economics Institute, 2011. 